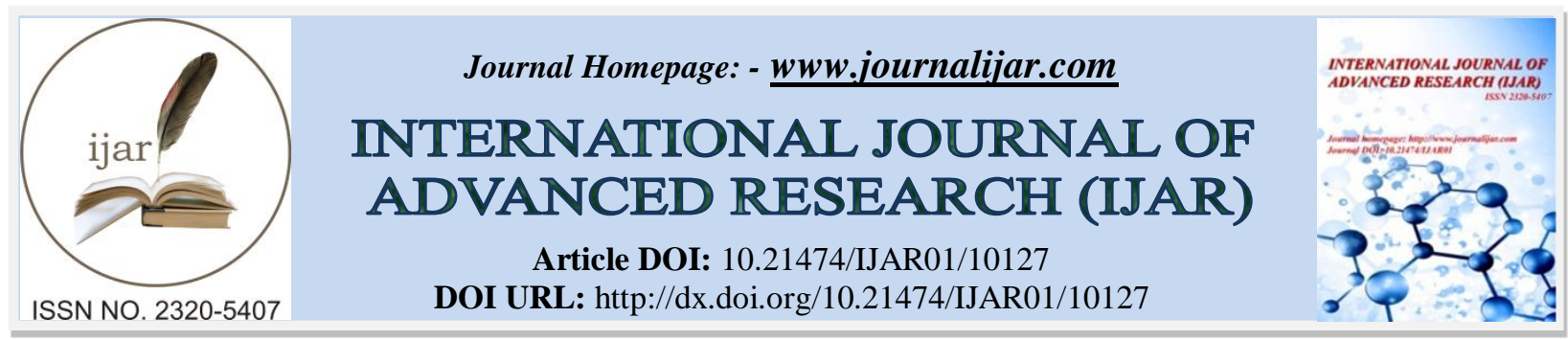

RESEARCH ARTICLE

\title{
ROLE OF BALA TAILA MATRA BASTI AND KEBUKA TAILA YONI PICHU IN SUKH PRASAVA WITH SPECIAL REFERENCE TO PROGRESS OF LABOR:A CASE REPORT.
}

Dr. Priyanka Hajare ${ }^{1}$, Dr. B. Pushpalatha ${ }^{2}$ and Dr. K. Bharathi ${ }^{3}$.

1. M.S Final Year,Scholar Prasuti tantra \& Stri roga dept.,National Institute of Ayurveda, Jaipur.

2. Asso. Professor, Prasuti tantra \& Stri roga dept.National Institute of Ayurveda, Jaipur.

3. HOD \& Professor, Prasuti tantra \& Stri roga dept.National Institute of Ayurveda, Jaipur.

\section{Manuscript Info}

\section{Manuscript History}

Received: 01 October 2019

Final Accepted: 03 November 2019

Published: December 2019

Key words:-

Apana Vayu, Garbha Nishkramana,

Prajasthapana, Brmhaniya.

\begin{abstract}
Background: A 26 years old woman first visited the NIA OPD on $16^{\text {th }}$ October 2019 for antenatal checkup. She was in eight month of her pregnancy. Methodology: She attended the antenatal clinic regularly, and complied with Ayurveda medication- Prawal pishti, Mukta Shukti bhasma, Dhatri loha \& Satavari churna with milk, with prenatal advice given to her from time to time. She had no obstetric or medical problems during the course of her pregnancy. Bala taila Matra Basti started from 37 weeks, was given twice weekly for consecutive two weeks. Then, followed by Kebuka taila Yoni Pichu two hourly from active phase of labor to full dilatation of cervix. Result: A FTND, an alive healthy Male child of wt. $3.1 \mathrm{kgs}$ delivered as vertex presentation on $06 / 12 / 2019$ at $7: 43 \mathrm{AM}$.
\end{abstract}

Copy Right, IJAR, 2019,. All rights reserved.

\section{Introduction:-}

Safe motherhood achieved by safe and complication free pregnancy and easy delivery i.e. Sukhprasava. Every woman tries to enter in this new world of mother with natural termination of pregnancy with minimum pain, operative aids and complications. For Sukhprasava, vata dosa should be in prakrit state. If apana vata is not maintained during pregnancy it will lead to abnormalities during prasava. Keeping this in mind Acharyas have stated Anuvsana Basti and Yoni Pichu in $9^{\text {th }}$ month for preventing vata vikriti and facilitates normal labour. As Anuvasana Basti favours vatanulomana, particularly apanavayu, which performs garbha nishkramana and Yoni Pichu favours snigdhata to muscles and ligaments of garbhashaya, hence the expulsion of fetus is not much difficult.

\section{Need Of The Study-}

1. The number of caesarean section deliveries in India has more than doubled in past decade, where Cervical dystocia (no progress of labor) is the contributing factor.

2. Labor is a natural physiological process and it is observed that the time taken for normal labor in primigravida is 12-14 hours and 6-8 hours in multiparas. The latent phase of labor should not exceed more than 8 hours in primigravida and 4 hours in multiparas . Thus, to avoid Prolonged labor and Obstructed labor, any intervention that eases and augments labor is well accepted, providing comfort to mother and foetus.

3. The use of Oxytocic drugs during labor causes distress and harmful effect to mother and fetus. To reduce the use of such drugs and to carry out normal vaginal delivery (Sukhprasava) with minimum aids, it is an effort to reduce complications, before and during delivery, as well as in early puerperium.

Corresponding Author:-Dr. Priyanka Hajare.

Address:-M.S Final Year,Scholar Prasuti tantra \& Stri roga dept.,National Institute of Ayurveda, Jaipur. 


\section{Aims And Objectives-}

Aim:

To study the effect of Bala taila Matra Basti \& Kebuka taila Yoni Pichu in Sukhprasava.

\section{Objectives:-}

1. To facilitate Prasava (Smooth delivery) \& to prevent injury of lower genital tract, uterine atony.

2. To observe the outcome of different stages of labor.

3. To prevent the complications of labor like postpartum hemorrhage.

\section{Type Of Study-}

Observational single case design without control group.

\section{Materials And Methods:-}

Literary Study

Literary references collected from Ayurveda i.e. classics, commentaries, modern literatures, research journals available in institute library, online portals like PubMed central, Ayush research portal, Google scholar and analyzed to frame conceptual work.

\section{Case Study -}

Selection of the patient

Routine ANC patient selected from OPD of NIA, Jaipur who was ready to give written voluntary informed consent before starting the trial.

\section{Study Details-}

1. Name of Patient- XXX

2. Registration no. -9804122019

3. Date of $1^{\text {st }}$ visit- 16.10.2019

4. Age- 26 years

5. Gender- Female

6. Religion- Hindu

7. Occupation- Housewife

\section{Chief complaints-}

1. Amenorrhea since 9 months.

2. labor pains since night (11:00 pm)

3. No H/O leaking $\mathrm{P} / \mathrm{V}$

4. No H/O Bleeding $\mathrm{P} / \mathrm{V}$

\section{History of Present Pregnancy-}

According to patient she was asymptomatic before 9 months. Then she developed the complaint of amenorrhea. She found her UPT +ve. She came to NIA Prasuti OPD for regular ANC work up. Bala taila Matra basti (60ml) was given to patient twice weekly for consecutive two weeks, after completion of 37 weeks. She was admitted in NIA IPD ward on 4.12.2019 with complaints of pain in lower abdomen. Labor pains start since 7:00 pm on 5.12.2019. Then, she was under observation for vitals, uterine contractions and fetal heart rate half hourly in IPD ward.

\section{History of the Patient-}

\section{Personal History-}

1. Diet- Mixed

2. Appetite- Satisfactory intake

3. Bowels- No complaints

4. Micturition- No complaints

5. Sleep- Sound

6. Medications- Nil

7. Habits- No history of using alcohol or tobacco. 
Medical \& Surgical History -

Not Significant.

Family History-

Not Significant.

Menstrual \& Marital History-

1. Menarche at age of 14 years.

2. Past Menstrual cycles: 4/ 30-35 days. Regular, moderate flow and painless.

3. Last menstrual period (LMP): $5^{\text {th }}$ March 2019.

4. Expected Date of Delivery (EDD): $12^{\text {th }}$ December 2019.

\section{Obstetric History- O/H- G2 P1 L1 A0}

1. G1- FTND. FCH of 4 years at gangori hospital.

2. G2- Present pregnancy

3. Married life: 5year

4. Active Married life: 5year

\section{Physical Examination-}

\section{General Examination-}

1. Height- $156 \mathrm{~cm}$

2. Weight- $54 \mathrm{~kg}$

3. TPR- Normal

4. B.P- $100 / 70 \mathrm{~mm} \mathrm{Hg}$

5. Averagely built and nourished

6. Pallor- Nil

7. No Pedal edema

8. Nails, tongue and conjunctiva- Pink

9. No evidence of lymphadenopathy

10. No evidence of any icterus

\section{Systemic Examination-}

Cardio-vascular system, Respiratory system and Central nervous system were normal.

\section{Prenatal Advice-}

1. The patient was advised to consume an adequate mixed diet, to include two glasses of milk, fruits, green leafy vegetables and chicken/eggs. To drink properly sterilized water. Avoid eating out, deep fried food, highly spiced or preserved foods. Avoid excess of tea or coffee.

2. Avoid unnecessary travel.

3. Avoid strenuous physical work.

4. Adequate bed rest.

5. Appointment made for visit for prenatal investigations.

6. Prawal Pishti $-500 \mathrm{mg}$ BD, Mukta Shukti bhasma- $500 \mathrm{mg}$ BD, Dhatri loha -2 tablets BD after food \& Satavari churna $3 \mathrm{gm}$ with Milk was advised.

7. To come for check-ups, every 15 days up to 36 weeks and weekly thereafter until term.

8. Patient explained to look out for any warning signs of danger and to immediately report any bleeding, undue swelling of feet, face or fingers, visual disturbances, severe headache, presence of any unusual vaginal discharge, diminished fetal movements or any other unexpected events or complaints of concern at any time.

\section{Antenatal Investigations-}

\section{Hemoglobin}

1. $10.1 \mathrm{~g} \%\left(24^{\text {th }}\right.$ April $)$

2. $\quad 11.3 \mathrm{~g} \%$ ( $11^{\text {th }}$ October)

3. $\quad 11.8 \mathrm{~g} \%\left(5^{\text {th }}\right.$ November $)$

4. $12.1 \mathrm{~g} \%\left(2^{\text {nd }}\right.$ December $)$ 
5. Blood group \& Rh type: 'A' Rh Positive

6. Urine routine: Normal

7. Random Blood Sugar (RBS): 98 mg\%

8. VDRL test: Non-reactive

9. Australia antigen (HBsAg) test: Non-reactive

10. HIV screening: Negative

11. TSH screening: $0.37 \mu \mathrm{IU} / \mathrm{ml}$ (Normal)

12. Ultrasound Scans:

13. Scan on $24^{\text {th }}$ April 2019 revealed single live gestation with gestational age 6 weeks, fetal heart sound present.

14. Scan on $19^{\text {th }}$ June 2019 revealed single live gestation with gestational age 16 weeks. Placenta- posterior upper, adequate liquor present.

15. Scan on 25th Sept 2019 revealed single live gestation with gestational age 28 weeks. Placenta- posterior upper, adequate liquor present. Estimated fetal weight $1286 \mathrm{gm}$.

16. Scan on $23^{\text {rd }}$ Oct 2019 revealed single live gestation with gestational age 30-31 weeks. Placenta- posterior upper, adequate liquor present. Estimated fetal weight $1671 \mathrm{gm}$.

17. Scan on $22^{\text {nd }}$ Nov 2019 revealed single live gestation with gestational age 35-36 weeks. Placenta- posterior upper Grade III, adequate liquor present. Estimated fetal weight $2708 \mathrm{gm}$.

Schedule Of Bala Taila Matra Basti-

\begin{tabular}{|l|l|l|}
\hline DATE & PERIOD OF GESTATION & BALA TAILA MATRA BASTI \\
\hline $19 / 11 / 2019$ & 37 weeks & $60 \mathrm{ml}$ \\
\hline $22 / 11 / 2019$ & 37 weeks 3 day & $60 \mathrm{ml}$ \\
\hline $27 / 11 / 2019$ & 38 weeks 1 day & $60 \mathrm{ml}$ \\
\hline $03 / 12 / 2019$ & 38 weeks 6 day & $60 \mathrm{ml}$ \\
\hline $04 / 12 / 2019$ & 39 weeks 1 day & $60 \mathrm{ml}$ \\
\hline
\end{tabular}

Labour Record-

\begin{tabular}{|c|c|c|c|c|}
\hline TIME & B.P & FHR & CONTRACTIONS & OTHERS \\
\hline $\begin{array}{l}6 / 12 / 19 \\
4.00 \mathrm{AM}\end{array}$ & $\begin{array}{l}110 / 70 \\
\mathrm{mmHg}\end{array}$ & $144 \mathrm{bpm}$ & $\begin{array}{c}2-35 \mathrm{sec} \\
40 \mathrm{sec}\end{array}$ & $\begin{aligned} & \text { P/V- } \\
& \text { - } 4-5 \mathrm{~cm} \quad \text { cervix } \\
& \text { dilatation } \\
& \text { - } 30-40 \% \\
& \text { effacement. } \\
& \text { - } \text { Head at }-2 \text { station. } \\
& \text { - } \text { Kebuka taila Yoni } \\
& \text { pichu applied. } \\
&\end{aligned}$ \\
\hline $4.30 \mathrm{AM}$ & $\begin{array}{l}100 / 60 \\
\mathrm{mmHg}\end{array}$ & $140 \mathrm{bpm}$ & $\begin{array}{c}-45 \mathrm{sec} \\
45 \mathrm{sec} \\
40 \mathrm{sec}\end{array}$ & - \\
\hline $5.30 \mathrm{AM}$ & $\begin{array}{l}110 / 70 \\
\mathrm{mmHg}\end{array}$ & $144 \mathrm{bpm}$ & $\begin{array}{r}3-40 \mathrm{sec} \\
55 \mathrm{sec} \\
50 \mathrm{sec}\end{array}$ & $\begin{aligned} \text { P/V- } & \\
\text { - } & 5-6 \mathrm{cms} \text { dilatation } \\
\text { - } & 60-70 \% \text { effacement } \\
\text { - } & \text { Head at -1 station } \\
\text { - } & \text { Membrane + } \\
\text { - } & \text { Kebuka taila Yoni } \\
& \text { Pichu applied } \\
& \text { again. }\end{aligned}$ \\
\hline $\begin{array}{l}7.00 \\
\text { AM }\end{array}$ & $\begin{array}{l}100 / 60 \\
\mathrm{mmHg}\end{array}$ & $140 \mathrm{bpm}$ & $\begin{array}{c}3-40 \mathrm{sec} \\
45 \mathrm{sec} \\
40 \mathrm{sec}\end{array}$ & $\begin{aligned} \text { P/V- } & \\
\text { - } & 7-8 \mathrm{~cm} \text { dilatation } \\
\text { - } & 80 \% \text { effacement }\end{aligned}$ \\
\hline
\end{tabular}




\begin{tabular}{|c|c|c|c|c|}
\hline & & & & $\begin{array}{ll}\text { - } & \text { Head at } 0 \text { station } \\
\text { - } & \text { Membrane }+\end{array}$ \\
\hline 7.30 AM & $\begin{array}{l}110 / 70 \\
\mathrm{mmHg}\end{array}$ & $\begin{array}{l}148 \\
\text { Bpm }\end{array}$ & $\begin{array}{c}\text { 4- } 45 \mathrm{sec} \\
45 \mathrm{sec} \\
40 \mathrm{sec} \\
40 \mathrm{sec}\end{array}$ & $\begin{array}{ll}\text { P/V- } \\
\text { - } \\
\text { Cervix fully dilated, } \\
\text { fully effaced } \\
\text { - Bag of membrane- } \\
\text { absent } \\
\text { - Liquor- clear. }\end{array}$ \\
\hline
\end{tabular}

\section{Observations \& Results:-}

Pain threshold during labor was moderate. Bearing down efforts (Pravahana) - good effort. The duration of $1^{\text {st }}$ stage of labor was significantly reduced 3 and half hours. Better cervical ripening and dilatation was seen. The $2^{\text {nd }}$ stage was uneventful with no delay, no cervical, vaginal or perineal tears seen. A Full term normal vaginal delivery (POG39 Weeks 2 days), an alive healthy Male child delivered as vertex presentation of weight $3.1 \mathrm{kgs}$ at 7.43 am on 06/12/2019. The baby cried well at birth, was pink in colour and the baby was active. APGAR Score at the end of 1 min was 7 , at $5 \mathrm{~min}$ was 8 and at $10 \mathrm{~min}$ was 10 . The $3^{\text {rd }}$ stage had mean placental expulsion time of 5-6 minutes. The lower genital tract was meticulously inspected. There was no injury apart.

As Bala taila Matra Basti favours vatanulomana, particularly apanavayu, which performs garbha nishkramana and Kebuka taila Yoni Pichu favours snigdhata to muscles and ligaments of garbhashaya, hence the expulsion of fetus was not much difficult.

The patient was closely watched for the next 2 hours after delivery. As the uterus was well contracted, there was no undue bleeding from the genital tract and her vital signs were satisfactory and stable. There were no complaints of after pains.

\section{Discussion:-}

As child bearing and delivery are physiological phenomenon and any abnormality in courses of labor can affect women health not only for that time being but also through her life. That's why for good health of mother and baby Sukhprasava is important. Labor is a painful experience with extreme uterine contractions and retractions, which is said to be under the action of prasuti maruta.

1. Bala taila matra basti affects the autonomous nervous system governing myometrium and help in regulating their function during labor. Kebuka taila Yoni pichu destroy pathogenic bacteria of vaginal canal and prevent puerperal sepsis, it also soften vaginal passage thus help in normal labor. It soften the perineum and help in its relaxation during labor.

2. Application of Kebuka taila yoni pichu provides strength to perineal muscles; it encourages cervical effacement and dialatation. It shortens the duration of labor. It prevents from apana vayu vilambit prasava.

3. Soft tissue injuries of the lower genital tract are not uncommon and often account for postpartum hemorrhage. Periurethral and periclitoral lacerations tend to bleed profusely. Cervical tear, vaginal tear and uterine atony cause profuse bleeding. That's why in order to prevent all these, bala taila matra basti \& Kebuka taila yoni pichu is essential in $9^{\text {th }}$ month of pregnancy to facilitate Sukhparasava because it favours snigdhata to muscles and ligaments of garbhashaya,

4. Acharya Caraka described Bala under Madhura skandha, Prajasthapana mahakashaya and brmhaniya. That's why it results in good weight and APGAR score of baby.

\section{Rationality Of Selection Of Trial Drug-}

In the present study Bala (Sida cordifolia Linn.) is selected. Acharya Caraka described Bala under Madhura skandha, Prajasthapana mahakashaya and brmhaniya. Bala is madhura rasa, madhura vipaka, snigdha guna,balya. Bala is also mentioned as a rejuvenate (rasayana). Acharya Susruta also described Bala among Madhura dravyas. The Root of Bala is known as good tonic and having balya (Strength promoting) property. On Pharmacological screening the drug is found to have Betaphenethylamine, Ephedrine, vasicinol, choline, hypaphorine methyl ester. 
Kebuka (Costus speciosus Koen.ex retz.sm), it is tikta-kashaya in property, aggrevates vata and acts through its garbhashaya sankochak prabhava. On Pharmacological screening the Rhizome of Kebuka is found to have Diosgenin, Costusosides, Saponins-dioscin, gracillin and beta-sitosterol-beta-D-glucoside. Diosgenin starch is hygroscopic in nature, due to which it absorbs water and soften the cervix. Diosgenin also has oestrogenic activity.

\section{Conclusion:-}

Ayurveda is the traditional system of Indian medicine. Every pregnant woman should follow Ayurveda masanumasik garbhini paricharya, mainly to prevent from anemia, because anemia increases the risk of postpartum hemorrhage and the two conditions together contribute to maternal death. Child birth is a very dynamic process and the women need to be well prepared for it. That's why for easy and smooth delivery, Bala taila matra basti and Kebuka taila yoni pichu favours to deliver mother with ease. Hence, we can conclude that Ayurveda principles when used wisely and with proper reference can definitely give good hand in the prevention \& treatment of today's complications as well as for mother \& child health care.

\section{References:-}

1. Tewari P.V. Ayurved Prasuti Tantra Evam Stri Roga- Prasuti Tantra (Obstetrics), Part 1 (2011), Chaukhamba Orientalia,Varanasi

2. Dutta DC, Text Book of Obstetrics, $7^{\text {th }}$ ed. Kolkata: New Central Book Agency (P) Ltd; 2011. Pp 688,Pg.116, Pg.401.

3. Shirish N Daftary, 100+ clinical cases in obstetrics, Elsevier, a division of reed Elsevier india private limited.

4. Tewari P.V. Ayurved Prasuti Tantra Evam Stri Roga- Prasuti Tantra (Obstetrics), Part 1 (2011), Chaukhamba Orientalia,Varanasi

5. Vd.Yadhavaji Trikamaji Acharya, Caraka samhita of Agnivesha elaborated by Caraka and Drudhabala with Ayurveda-Dipika commentary by Chakrapanidatta, Chaukhamba Sanskrit sansthan, 2014, Page no. 346.

6. Kaviraj Ambika Dutta Shastri, Susruta Samhita, Chaukambha Sanskrit Sansthan, Varanasi.

7. Kaidevnighantu (Pathyapathyavibhodhak) by Acharya P.V. Sharma, Chaukhambha orientalia, Varanasi. Pg.643- Aushadhivarg.

8. Dravyagunavijnana, Volume-II by Acharya P.V Sharma, Chaukhambha bharati academy, Varanasi. Pg.606.

9. Medicinal Herbs with their Formulations by Dr. M.P Singh and Himadri Panda (2005), Daya publishing house, Delhi. P g. 297-298. 